\title{
Outcomes of autologous bone marrow mononuclear cells for cerebral palsy: an open label uncontrolled clinical trial
}

\author{
Liem Thanh Nguyen ${ }^{1 *}$, Anh Tuan Nguyen ${ }^{1}$, Chinh Duy Vu' ${ }^{2}$, Doan V. Ngo ${ }^{3}$ and Anh V. Bui ${ }^{1}$
}

\begin{abstract}
Background: Stem cell therapy has emerged as a promising method for improving motor function of patients with cerebral palsy. The aim of this study is to assess the safety and effectiveness of autologous bone marrow mononuclear stem cell transplantation in patients with cerebral palsy related to oxygen deprivation.

Methods: An open label uncontrolled clinical trial was carried out at Vinmec International Hospital. The intervention consisted of two administrations of stem cells, the first at baseline and the second 3 months later. Improvement was monitored at 3 months and 6 months after the first administration of stem cells, using the Gross Motor Function Measure (GMFM) and Modified Ashworth Score which measures muscle tone.

Results: No severe complications were recorded during the study. After transplantation, 12 patients encountered fever without infections and 9 patients experienced vomiting which was easily managed with medications. Gross motor function was markedly improved 3 months or 6 months after stem cell transplantation than at baseline. The post-transplantation GMFM-88 total score, each of its domains and the GMFM-66 percentile were all significantly higher ( $p$-value $<0.001$ ). Muscle spasticity also reduced significantly after transplantation ( $p$-value $<0.001)$. The therapy was equally effective regardless of sex, age and GMFCS level ( $p$-value $>0.05$ ).
\end{abstract}

Conclusion: Autologous bone marrow mononuclear cell transplantation appears to be a safe and effective therapy for patients with cerebral palsy.

Trial registration: ClinicalTrials.gov Identifier: NCT02569775. Retrospectively registered on October 15, 2015.

Keywords: Cerebral palsy, Stem cells

\section{Background}

Cerebral palsy is a non-progressive brain disorder affecting movement and posture. Its prevalence is 2.11 cases per 1000 live births (95\% confidence interval [CI] 1.98-2.25) [1] . Management of cerebral palsy includes physical therapy, neurectomy, botulinum toxin A and medications, however these could not cure the disease [2]. Stem cell therapy has emerged as a promising method for improving motor function of patients with cerebral palsy.

\footnotetext{
* Correspondence: v.liemnt-ceo@vinmec.com

${ }^{1}$ Stem cells and Gene Technology Research Center, Vinmec International Hospital, 458 Minh Khai Street, Hanoi, Vietnam

Full list of author information is available at the end of the article
}

Positive findings on motor improvement were demonstrated in animal models [3-5]. However, the mechanism of action by which stem cells exert their effects in cerebral palsy is still a topic of controversy. Some studies showed that stem cells could differentiate into neurons, oligodendrocytes and astrocytes [6-10]. Many other studies suggested that it was not the stem cell differentiation that would replace the injured cells but that the stem cells secreted trophic factors and cytokines, which modulate the micro environment, support anti-inflammation, cytoprotection and angiogenesis; generate myelinproducing cells and stimulate endogenous stem cells in the brain [11-15]. 
Stem cell therapy for cerebral palsy was shown to be safe and effective in human studies as well [11, 16-23]. Nevertheless, the number of studies on this promising intervention are still limited. More scientific evidence is needed to provide support for stem cell therapy as a standard of care for cerebral palsy.

The aim of this clinical study is to evaluate the safety and effectiveness of autologous bone marrow mononuclear cells (BMMNCs) in the management of cerebral palsy related to oxygen deprivation at Vinmec International Hospital, Hanoi, Vietnam.

\section{Methods}

\section{Study design}

An open label uncontrolled clinical trial of 40 patients aged 2 to 15 with cerebral palsy was conducted. The study commenced in April 2014 and completed in August 2015.

\section{Patient selection criteria}

Patients diagnosed with cerebral palsy of any type related to oxygen deprivation at Vinmec International Hospital, Hanoi, Vietnam were included in this study. The exclusion criteria were GMFCS level I\&II, epilepsy, hydrocephalus with ventricular drain, coagulation disorders, allergy to anesthetic agents, severe health conditions such as cancer, failure of heart, lung, liver or kidney and active infections.

\section{Intervention}

The intervention included 2 intrathecal administrations of autologous Bone Marrow Mononuclear Cells (BMMNCs) at baseline and 3 months afterward conducted by certified anesthesiologists.

\section{Isolation of BMMNCs}

Bone marrow aspiration was performed under general anesthesia in the operating theatre. The volume collected depends on the patients' body weight as followed: $8 \mathrm{ml} / \mathrm{kg}$ for patients under $10 \mathrm{~kg}$; [80 $\mathrm{ml}+$ (body weight in $\mathrm{kg}-10) \times 7 \mathrm{ml}$ ] for patients above $10 \mathrm{~kg}$ but no more than $200 \mathrm{ml}$ in total. BMMNCs were separated from the aspirate using the density gradient centrifugation using Ficoll [24]. The BMMNCs, Hematopoietic stem cells (CD34+ cells) were counted and checked for viability by Flowcytometry method.

\section{Transplantation of BMMNCs}

The BMMNCs were divided into two doses: one was given immediately after processing and the rest was stored in liquid nitrogen at minus 196 degree Celsius and administered 3 months after the first dose. The average numbers of mononuclear cells and CD34+ cells per $1 \mathrm{~kg}$ body weight transplanted for the first time were
$27.2 \times 10^{6}$ and $2.6 \times 10^{6}$, respectively. The corresponding numbers for the second time were $17.1 \times 10^{6}$ and $1.7 \times 10^{6}$. The average of cell viability before the 1 st and the 2 nd injection was $97.8 \% \%$ and $72 \%$, respectively. The route of administration was intrathecal between the 4th and 5th lumbar vertebrae. Each dose of cells was mixed with saline to reach a volume of $10 \mathrm{ml}$ for administration. An 18 gauge needle was used to ensure that cells were not sheared by the injection. The procedures were conducted in the recovery room and lasted for $30 \mathrm{~min}$.

\section{Clinical assessment}

Thorough clinical examinations were performed by a certified and experienced rehabilitation specialist at baseline, 3 months and 6 months afterwards with a special focus on the motor function. Children's functional ability was classified based on Gross Motor Function Classification System (GMFCS) [25]. In order to evaluate the changes in motor function over time, a standardized observational tool namely the Gross Motor Function Measure (GMFM)-88 [26] was used. The GMFM-88 consists of 88 items categorized into five domains as followed: A. Lying and Rolling; B. Sitting; C. Crawling and Kneeling; D. Standing; E. Walking, Running and Jumping. The raw scores were entered into a computer program namely Gross Motor Ability Estimator to calculate the overall total scores, subtotal scores of each domains or to convert the GMFM-88 scores to GMFM-66 percentiles. The GMFM-66 percentile shows the relative motor function of a patient compared to children of the same age and GMFCS therefore it helped to exclude the interference of improvement with age [27]. Besides, muscle tone was assessed by Modified Ashworth Score [28].

GMFM-88 and GMFM-66 percentiles were primary outcomes. Modified Ashworth Score was secondary outcome.

\section{Laboratory and imaging diagnostics}

Magnetic resonance imaging and electroencephalography of the brain, hematologic and biochemistry profile including $\mathrm{HIV}, \mathrm{HBV}$, and $\mathrm{HCV}$ tests were performed on all patients.

\section{Statistical analysis}

Each individual is a unit of analysis. Paired t-test was used to compare the motor function and muscle tone at 3 months and 6 months with those at baseline. T-test or one-way ANOVA was used to further investigate changes in motor function and muscle tone according to patients' characteristics. A $p$-value less than 0.05 was considered statistically significant. All statistical analyses were performed using STATA 11 (StataCorp, College Station, Texas). 


\section{Results}

\section{Patients' characteristics}

A cohort of 40 patients with cerebral palsy was included in this study. There were 33 males (82.5\%) and 7 females (17.5\%). The age median was 4 years old (range: 1-12 years old). The type of cerebral palsy observed in all patients was spastic (38 with bilateral paresis and 2 with unilateral paresis). The severity according to GMFCS was as followed: 2 (5\%) with level III, 14 (35\%) with level IV and 24 (60\%) with level V. Three most common patterns found on MRI diagnostics are basal ganglia damage (39\%), cortical/sub-cortical damage (8\%) and periventricular white matter injury (8\%). Patients' characteristics are summarized in Table 1.

\section{Adverse events}

No complications were recorded during the procedure. After transplantation, mild fever was observed in $12(30 \%)$ of the cases without any identified or suspected infections. Nine (22.5\%) of the patients had intermittent vomiting which was also well managed with medications. Adverse events during and after stem cell transplantation are described in Table 2 .

Table 1 Patients' characteristics

\begin{tabular}{|c|c|}
\hline Characteristics & $N=40(100 \%)$ \\
\hline \multicolumn{2}{|l|}{ Sex } \\
\hline Male & $33(82.5 \%)$ \\
\hline Female & $7(17.5 \%)$ \\
\hline \multicolumn{2}{|l|}{ Age } \\
\hline$<5$ years old & $25(62 \%)$ \\
\hline $5-10$ years old & $13(32 \%)$ \\
\hline$>10$ years old & $2(6 \%)$ \\
\hline \multicolumn{2}{|l|}{ Type of Cerebral Palsy } \\
\hline Bilateral spastic & $38(95 \%)$ \\
\hline Unilateral spastic & $2(5 \%)$ \\
\hline \multicolumn{2}{|l|}{ GMFCS } \\
\hline Level III & $2(5 \%)$ \\
\hline Level IV & $14(35 \%)$ \\
\hline Level V & $24(60 \%)$ \\
\hline \multicolumn{2}{|l|}{ MRI patterns } \\
\hline Periventricular white matter injury & $8(22 \%)$ \\
\hline Focal infarction & $1(3 \%)$ \\
\hline Cortical/Sub-cortical damage & $8(22 \%)$ \\
\hline Basal ganglia damage & $14(39 \%)$ \\
\hline Miscellaneous & $5(14 \%)$ \\
\hline
\end{tabular}

Table 2 Adverse events during and after stem cell transplantation

\begin{tabular}{ll}
\hline Adverse events & $\mathrm{N}(\%)$ \\
\hline Fever after transplantation & $12(30 \%)$ \\
Vomiting after transplantation & $9(22.5 \%)$ \\
Seizures after transplantation & $0(0 \%)$ \\
Other complications & $0(0 \%)$ \\
\hline
\end{tabular}

Gross motor function and muscle tone before and after stem cell transplantation

Gross motor function improved remarkably after stem cell transplantation as compared to the baseline scores. The post-transplantation total GMFM-88 score and all of its domains were significantly higher (paired t-tests, $p$ - value $=0.001$ in domain $\mathrm{E}$ and $<0.0001$ in the rest). Proportion of patients with improvement by GMFM domains were as follows: 100\% in domain A (Lying and Rolling) and domain B (Sitting); $71 \%$ in domain C (Crawling and Kneeling); 64\% in domain D (Standing); $38 \%$ in domain $\mathrm{E}$ (Walking, Running and Jumping). The GMFM-66 percentile measured only the relative motor function of the child as compared to other children of the same GMFCS and age. It was used to control for the possible improvement with age. The GMFM-66 percentile also improved significantly at 3 months after transplantation (Mean: 82.3\%, 95\% CI: [76.0; 88.5]) and 6 months after transplantation (Mean: 84.6\%, 95\% CI: [78.3; 90.8] as compared with baseline (Mean: 31.7\%, 95\% CI: [24.9; 38.5]). Muscle tone fell significantly from the mean modified Ashworth score of 3.4 at the baseline to 2.1 at 3 months and 2.0 at 6 months after the first transplantation (paired $\mathrm{t}$ test, $p$-value $<0.001$ ). Gross Motor Function Measure and Muscle tone before and after stem cell transplantation are demonstrated in Table 3.

\section{Changes in gross motor function measure, muscle tone according to patients' characteristics}

Changes in gross motor function and muscle tone before and 6 months after stem cell transplantation were further analyzed by patients' characteristics. The results are shown in Table 4.

There was a trend for females to have better improvement in both gross motor function and muscle tone, but these findings were not statistically significant. Age and GMFCS level did not show any significant improvement of gross motor function and muscle tone.

\section{Discussion}

In our study of the 40 patients with cerebral palsy related to oxygen deprivation, transplantation of autologous BMMNCs was apparently safe with no adverse events recorded during the procedure. During hospital stay after transplantation, 12 patients had mild fever but 
Table 3 Gross Motor Function Measure and Muscle tone before and after stem cell transplantation

\begin{tabular}{llll}
\hline & $\begin{array}{l}\text { Baseline } \\
\text { Mean }[95 \% \mathrm{Cl}]\end{array}$ & $\begin{array}{l}3 \text { months } \\
\text { post-transplantation } \\
\text { Mean }[95 \% \mathrm{Cl}]\end{array}$ & $\begin{array}{l}6 \text { months } \\
\text { post-transplantation } \\
\text { Mean [95\% Cl] }\end{array}$ \\
\hline Total GMFM-88 & $16.7[12.3 ; 21.1]$ & $38.9[32.2 ; 45.6]^{*}$ & $41.8[34.8 ; 48.7]^{*}$ \\
A. Lying \& rolling & $48.4[41.2 ; 55.5]$ & $87.8[83.5 ; 92.1]^{*}$ & $91.7[88.0 ; 95.3]^{*}$ \\
B. Sitting & $24.0[16.5 ; 31.5]$ & $55.1[46.0 ; 64.3]^{*}$ & $59.5[50.4 ; 68.7]^{*}$ \\
C. Crawling \& kneeling & $8.7[3.5 ; 13.8]$ & $30.2[18.9 ; 41.5]^{*}$ & $33.3[21.4 ; 45.2]^{*}$ \\
D. Standing & $4.0[0.9 ; 7.1]$ & $17.9[10.1 ; 25.7]^{*}$ & $20.2[11.5 ; 28.8]^{*}$ \\
E. Walking, running \& jumping & $1.2[0.1 ; 2.4]$ & $5.8[2.2 ; 9.5]^{* *}$ & $6.5[2.5 ; 10.4]^{* *}$ \\
GMFM-66 & $24.8[21.4 ; 28.1]$ & $38.2[34.6 ; 41.8]^{*}$ & $40.0[36.3 ; 43.6]^{*}$ \\
GMFM-66 percentiles & $31.7[24.9 ; 38.5]$ & $82.3[76.0 ; 88.5]^{*}$ & $84.6[78.3 ; 90.8]^{*}$ \\
Modified ashworth score & $3.4[3.2 ; 3.6]$ & $2.1[1.9 ; 2.3]^{*}$ & $2.0[1.8 ; 2.2]^{*}$ \\
\hline
\end{tabular}

${ }^{*} p$-value $<0.0001$ (paired t-test, compared to baseline)

${ }^{* *} p$-value $=0.001$ (paired t-test, compared to baseline)

there were no signs of infections. Nine patients experienced intermittent vomiting, which was either selflimiting or relieved with medications. In a study of similar interventions on 40 patients by Sharma et al. demonstrated, $30 \%$ had vomiting and $2.5 \%$ had diarrhea [16]. In two other studies, there were no visible side effects or adverse reactions [11, 17].

GMFM improved remarkably after stem cell transplantation as compared to those in the baseline. The post-transplantation total GMFM-88 score, all of its domains and the GMFM-66 percentile were significantly higher. Muscle spasticity also reduced significantly after transplantation. Similar positive findings were also observed in other clinical studies $[11,16,17]$. In those studies, the improvement could be seen as early as 1 month and was most remarkable during the first 6 months after transplantation. In another study, positive changes continued till 18 months of follow-up but tended to slow down over time [11].
We further analyzed changes in gross motor function and muscle tone before and 6 months after stem cell transplantation by patient characteristics and doses of stem cells. The therapy was equally effective regardless of sex, age and GMFCS level.

Autologous stem cells were used in this study so there were no risks of rejection, anaphylaxis or side effects of immunosuppressive drugs that go along with allogenic transplantations. In a trial using allogenic stem cells from umbilical cord blood, severe adverse events such as pneumonia, influenza, urinary tract infection or even death were observed [29]. Different routes of cell administration have been used for patients with cerebral palsy such as intralthecal, intracranial and intravenous injection. In our study, stem cells were administered intrathecally so it was minimally invasive. Intracranial transplantation seems more targeted at the sites of lesions (i.e. the brain) but it was not chosen by our research

Table 4 Changes in Gross Motor Function Measure, Muscle tone before and 6 months after stem cell transplantation according to patients' characteristics

\begin{tabular}{|c|c|c|c|}
\hline Characteristics & $\begin{array}{l}\text { Change in GMFM-88 total score } \\
\text { Mean }[95 \% \mathrm{CI}]\end{array}$ & $\begin{array}{l}\text { Change in GMFM- } 66 \text { percentile } \\
\text { Mean }[95 \% \mathrm{CI}]\end{array}$ & $\begin{array}{l}\text { Change in Ashworth score } \\
\text { Mean }[95 \% \mathrm{Cl}]\end{array}$ \\
\hline Sex & $p$-value $=0.09$ & $p$-value $=0.68$ & $p$-value $=0.88$ \\
\hline Male & $23.6[19.3 ; 27.8]$ & $52.2[44.5 ; 60.0]$ & $1.4[1.2 ; 1.6]$ \\
\hline Female & $32.1[22.6 ; 41.6]$ & $56.0[34.8 ; 77.2]$ & $1.4[0.9 ; 1.9]$ \\
\hline Age & $p$-value $=0.07$ & $p$-value $=0.32$ & $p$-value $=0.89$ \\
\hline$<5$ years old & $23.6[19.4 ; 27.7]$ & $52.5[44.0 ; 61.1]$ & $1.4[1.1 ; 1.6]$ \\
\hline 5-10 years old & $27.1[19.4 ; 34.8]$ & $52.4[39.3 ; 65.5]$ & $1.5[1.1 ; 1.8]$ \\
\hline$>10$ years old & $31.0[-273.9 ; 336.0]$ & $60.5[-390.6 ; 551.6]$ & $1.5[-4.9 ; 7.9]$ \\
\hline GMFCS & $p$-value $=0.23$ & $p$-value $=0.66$ & $p$-value $=0.90$ \\
\hline Level III & $33.5[-49.1 ; 116.1]$ & $63.5[-44.5 ; 171.5]$ & $1.5[-4.9 ; 7.9]$ \\
\hline Level IV & $34.4[27.4 ; 41.4]$ & $57.6[43.5 ; 71.7]$ & $1.6[1.3 ; 1.9]$ \\
\hline Level V & 18.9 [15.6; 22.2] & $49.2[40.5 ; 57.9]$ & $1.3[1.1 ; 1.5]$ \\
\hline
\end{tabular}


team due to the invasive nature of this procedure. Moreover, in a study by Chen et al. using both methods of cell administrations, intra-cerebral surgery did not demonstrate a superior effect when compared to intrathecal transplantation [17]. Intravenous injection was not our route of choice. In animal models, it was observed that most of the IV transplanted cells were caught at the lung, spleen, kidney and intestine [30]. The strategy to transplant autologous BMMNCs intrathecally was also applied in other studies $[11,16,20]$.

Our study has some limitations. It was an open label uncontrolled clinical trial as in some other studies $[11,16]$. The follow-up time of 6 months was relatively short. There might be more long term improvement such as social-behavioral development or quality of life that to be monitored and evaluated.

\section{Conclusions}

Based on the results of this study, we can conclude that autologous BMMNCs transplantation appears to be a safe and effective therapy for patients with cerebral palsy related to oxygen deprivation after 6 months of followup. Further studies are needed to examine the optimal regimen for this therapy and its long term effect ideally in double blind controlled trials.

\section{Additional file}

Additional file 1: Stem cell transplantation for cerebral palsy. This is a dataset file of study on autologous bone marrow mononuclear cells for cerebral palsy. The data includes demographic data, gross motor function of patients with cerebral palsy such as GMFM-88 total score, GMFM-66 percentile, and complication figures. The dataset consists of 40 observations and 44 variables (XLSX $51 \mathrm{~kb}$ )

\section{Abbreviations}

BMMNCs: Bone marrow mononuclear cells; GMFCS: Gross motor function classification system; GMFM: Gross motor function measure; MSCs: Mesenchymal stem cells

\section{Acknowledgements}

The authors acknowledge Professor Garry Warne, Royal Children's Hospital, Melbourne, Australia and Yvonne Osborne, PhD, Vinmec International Hospital, Vietnam for editing English for our manuscript.

\section{Funding}

We did not receive any funding to conduct this study.

\section{Availability of data and materials}

All data generated or analyzed during this study are included in this published article and its Additional file 1.

\section{Authors' contributions}

LTN, ATN, CDV, DVN, AVB: participated in the study concept, design and data collection. ATN: did data analysis. LTN, ATN, CDV, AVB participated in acquisition and interpretation of the data, drafted the manuscript. All authors have read and approved the final version of the manuscript.

\section{Competing interests}

The authors declare that they have no competing interests.

\section{Consent for publication}

Parental written informed consent was obtained well before patient enrollment in every case. This consent included their agreement on publishing patients' indirect identifiers such as age and gender.

\section{Ethics approval and consent to participate}

The study protocol was reviewed and approved by the Institutional Review Board of Vinmec International Hospital on March 10, 2014. The reference number for the ethics committee is 381/2015/QDVINMEC. The committee evaluated the ethical aspects of the study in accordance with The World Medical Association Declaration of Helsinki [29]. The study was explained in details to the parents of the participants. Parental written informed consent was obtained well before patient enrollment in every case.

\section{Publisher's Note}

Springer Nature remains neutral with regard to jurisdictional claims in published maps and institutional affiliations.

\section{Author details}

'Stem cells and Gene Technology Research Center, Vinmec International Hospital, 458 Minh Khai Street, Hanoi, Vietnam. ${ }^{2}$ Department of Rehabilitation, Vinmec International Hospital, 458 Minh Khai Street, Hanoi, Vietnam. ${ }^{3}$ Department of Diagnostic Imaging, Vinmec International Hospital, 458 Minh Khai Street, Hanoi, Vietnam.

Received: 14 December 2015 Accepted: 5 April 2017

Published online: 12 April 2017

\section{References}

1. Oskoui M, Coutinho F, Dykeman J, Jetté N, Pringsheim T. An update on the prevalence of cerebral palsy: a systematic review and meta-analysis. Dev Med Child Neurol. 2013;55:509-19. [cited 2016 Oct 15]. Available from: http://www.ncbi.n/m.nih.gov/pubmed/23346889.

2. Koman LA, Smith BP, Shilt JS. Cerebral palsy. Lancet. 2004;363(9421):1619-31. [cited 2015 Sep 24]. Available from: https://www.ncbi.n/m.nih.gov/pubmed/ ?term $=15145637$.

3. Brenneman M, Sharma S, Harting M, Strong R, Cox CS, Aronowski J, et al. Autologous bone marrow mononuclear cells enhance recovery after acute ischemic stroke in young and middle-aged rats. J Cereb Blood Flow Metab. 2010;30:140-9. [cited 2015 Sep 24]. Available from: http:// www.pubmedcentral.nih.gov/articlerender.fcgi?artid=2893568\&tool= pmcentrez\&rendertype=abstract.

4. Jansen EM, Solberg L, Underhill S, Wilson S, Cozzari C, Hartman BK, et al. Transplantation of fetal neocortex ameliorates sensorimotor and locomotor deficits following neonatal ischemic-hypoxic brain injury in rats. Exp Neurol. 1997;147:487-97. [cited 2015 Sep 24]. Available from: http://www.ncbi.nlm. nih.gov/pubmed/9344572.

5. Meier C, Middelanis J, Wasielewski B, Neuhoff S, Roth-Haerer A, Gantert M, et al. Spastic paresis after perinatal brain damage in rats is reduced by human cord blood mononuclear cells. Pediatr Res. 2006;59:244-9. [cited 2015 Sep 20]. Available from: http://www.ncbi.nlm.nih.gov/pubmed/ 16439586.

6. Mezey E, Chandross KJ, Harta G, Maki RA, SR MK. Turning blood into brain: cells bearing neuronal antigens generated in vivo from bone marrow. Science. 2000;290:1779-82. [cited 2015 Sep 26]. Available from: http://www. ncbi.nlm.nih.gov/pubmed/11099419.

7. Qu S, Luan Z, Yin G, Guo W, Hu X, Wu N, et al. Transplantation of human fetal neural stem cells into cerebral ventricle of the neonatal rat following hypoxic-ischemic injury: survival, migration and differentiation. Zhonghua $\mathrm{Er}$ Ke Za Zhi. 2005;43:576-9. [cited 2015 Sep 26]. Available from: http://www. ncbi.nlm.nih.gov/pubmed/16191264.

8. Chen A, Siow B, Blamire AM, Lako M, Clowry GJ. Transplantation of magnetically labeled mesenchymal stem cells in a model of perinatal brain injury. Stem Cell Res. 2010;5:255-66. [cited 2015 Sep 20]. Available from: http://www.ncbi.n/m.nih.gov/pubmed/20875955.

9. Park Kl, Himes BT, Stieg PE, Tessler A, Fischer I, Snyder EY. Neural stem cells may be uniquely suited for combined gene therapy and cell replacement: evidence from engraftment of Neurotrophin-3-expressing stem cells in hypoxic-ischemic brain injury. Exp Neurol. 2006;199:179-90. 
[cited 2015 Sep 20]. Available from: http://www.ncbi.nlm.nih.gov/ pubmed/16714016.

10. Mezey E, Key S, Vogelsang G, Szalayova I, Lange GD, Crain B. Transplanted bone marrow generates new neurons in human brains. Proc Natl Acad Sci U S A. 2003;100:1364-9. [cited 2015 Sep 26]. Available from: http://www. pubmedcentral.nih.gov/articlerender.fcgi?artid=298778\&tool=pmcentre $z \&$ rendertype $=$ abstract

11. Wang X, Cheng H, Hua R, Yang J, Dai G, Zhang Z, et al. Effects of bone marrow mesenchymal stromal cells on gross motor function measure scores of children with cerebral palsy: a preliminary clinical study. Cytotherapy. 2013;15:1549-62. [cited 2015 Jun 18]. Available from: http://www.ncbi.nlm.nih.gov/pubmed/24100132

12. Alvarez $\mathrm{P}$, Carrillo E, Vélez C, Hita-Contreras F, Martínez-Amat A, Rodríguez-Serrano $F$, et al. Regulatory systems in bone marrow for hematopoietic stem/progenitor cells mobilization and homing. Biomed Res. Int 2013;2013:312656. [cited 2015 Sep 18]. Available from: http://www.pubmedcentral.nih.gov/articlerender.fcgi?artid=3703413\& tool=pmcentrez\&rendertype=abstract.

13. Goldman SA. Progenitor cell-based treatment of the pediatric myelin disorders. Arch. Neurol 2011;68:848-56. [cited 2015 Sep 20]. Available from: http://www.pubmedcentral.nih.gov/articlerender.fcgi?artid=3358919\&tool= pmcentrez\&rendertype $=$ abstract.

14. Daadi MM, Davis AS, Arac A, Li Z, Maag A-L, Bhatnagar R, et al. Human neural stem cell grafts modify microglial response and enhance axonal sprouting in neonatal hypoxic-ischemic brain injury. Stroke 2010;41:516-523. [cited 2015 Sep 20]. Available from: http://www.ncbi.nlm.nih.gov/pubmed/ 20075340.

15. Gnecchi M, Zhang Z, Ni A, Dzau VJ. Paracrine mechanisms in adult stem cell signaling and therapy. Circ Res 2008;103:1204-19. [cited 2015 Mar 31]. Available from: http://www.pubmedcentral.nih.gov/articlerender.fcgi?artid= 2667788\&tool=pmcentrez\&rendertype $=$ abstract.

16. Sharma A, Sane H, Gokulchandran N, Kulkarni P, Gandhi S, Sundaram J, et al. A clinical study of autologous bone marrow mononuclear cells for cerebral palsy patients: a new frontier. Stem Cells Int 2015;2015:905874. [cited 2015 Sep 24]. Available from: http://www.pubmedcentral.nih.gov/articlerender. fcgi?artid $=4348592 \&$ tool $=$ pmcentrez\&rendertype $=$ abstract.

17. Chen G, Wang $Y, X u Z$, Fang F, Xu R, Wang Y, et al. Neural stem cell-like cells derived from autologous bone mesenchymal stem cells for the treatment of patients with cerebral palsy. J Transl Med 2013;11:21. [cited 2015 Aug 25]. Available from: http://www.pubmedcentral.nih.gov/ articlerender.fcgi?artid $=3563497 \&$ tool $=$ pmcentrez\&rendertype $=$ abstract.

18. He S, Luan Z, Qu S, Qiu X, Xin D, Jia W, et al. Ultrasound guided neural stem cell transplantation through the lateral ventricle for treatment of cerebral palsy in children. Neural Regen Res 2012;7:2529-35. [cited 2015 Sep 20]. Available from: http://www.pubmedcentral.nih.gov/articlerender.fcgi?artid= 4200709\&tool=pmcentrez\&rendertype $=$ abstract.

19. Jensen A, Hamelmann E. First autologous cell therapy of cerebral palsy caused by hypoxic-ischemic brain damage in a child after cardiac arrestindividual treatment with cord blood. Case Rep Transplant 2013;2013: 951827. [cited 2015 Sep 24]. Available from: http://www.pubmedcentral.nih. gov/articlerender.fcgi?artid=3671311\&tool=pmcentrez\&rendertype=abstract.

20. Mancías-Guerra C, Marroquín-Escamilla AR, González-Llano O, VillarrealMartínez L, Jaime-Pérez JC, García-Rodríguez F, et al. Safety and tolerability of intrathecal delivery of autologous bone marrow nucleated cells in children with cerebral palsy: an open-label phase I trial. Cytotherapy. 2014; 16:810-20. [cited 2015 Sep 8]. Available from: http://www.ncbi.nlm.nih.gov/ pubmed/24642016.

21. Min K, Song J, Kang JY, Ko J, Ryu JS, Kang MS, et al. Umbilical cord blood therapy potentiated with erythropoietin for children with cerebral palsy: a double-blind, randomized, placebo-controlled trial. Stem Cells 2013;31:581-91. [cited 2015 Sep 20]. Available from: http://www.pubmedcentral.nih.gov/ articlerender.fcgi?artid $=3744768 \&$ tool=pmcentrez\&rendertype $=$ abstract.

22. Purandare C, Shitole DG, Belle V, Kedari A, Bora N, Joshi M. Therapeutic potential of autologous stem cell transplantation for cerebral palsy. Case Rep. Transplant 2012;2012:825289. [cited 2015 Sep 24]. Available from: https://www.ncbi.nlm.nih.gov/pubmed/25593078.

23. Wang $X$, Hu H, Hua R, Yang J, Zheng P, Niu X, et al. Effect of umbilical cord mesenchymal stromal cells on motor functions of identical twins with cerebral palsy: pilot study on the correlation of efficacy and hereditary factors. Cytotherapy. 2015;17:224-31. [cited 2015 Sep 8]. Available from: http://www.ncbi.nlm.nih.gov/pubmed/25593078.
24. Ficoll-Hypaque Density Gradient Centrifugation. [cited 2015 Sep 25]. Available from: https://www.urmc.rochester.edu/rhic/documents/HIC-10020Approved.pdf.

25. Palisano, Rosenbaum B \& L. Gross Motor Function Classification System. [cited 2015 Sep 25]. Available from: https://canchild.ca/system/tenon/assets/ attachments/000/001/399/original/GMFCS_English_Illustrations.pdf.

26. Russel D. GMFM-88 Score Sheet. [cited 2015 Sep 25]. Available from: https://canchild.ca/system/tenon/assets/attachments/000/000/218/ original/gmfm-88_and_66_scoresheet.pdf.

27. Hanna SE, Bartlett DJ, Rivard LM, Russell DJ. Reference curves for the gross motor function measure: percentiles for clinical description and tracking over time among children with cerebral palsy. Phys Ther. 2008;88:596-607.

28. Modified Ashworth Scale Instructions.pdf. [cited 2015 Sep 25]. Available from: https://www.med-iq.com/files/noncme/material/pdfs/DOC\%201Modified\%20Ashworth\%20Scale.pdf.

29. Min K, Song J, Kang JY, Ko J, Ryu JS, Kang MS, et al. Umbilical cord blood therapy potentiated with erythropoietin for children with cerebral palsy: a double-blind, randomized, placebo-controlled trial. Stem Cells 2013;31:581-91. [cited 2015 Sep 20]. Available from: http://onlinelibrary.wiley.com/doi/10.1002/ stem.1304/abstract.

30. Steiner B, Roch M, Holtkamp N, Kurtz A. Systemically administered human bone marrow-derived mesenchymal stem home into peripheral organs but do not induce neuroprotective effects in the MCAo-mouse model for cerebral ischemia. Neurosci Lett 2012:513:25-30. [cited 2015 Sep 26]. Available from: https://www.ncbi.nlm.nih.gov/pubmed/22342911.

\section{Submit your next manuscript to BioMed Central and we will help you at every step:}

- We accept pre-submission inquiries

- Our selector tool helps you to find the most relevant journal

- We provide round the clock customer support

- Convenient online submission

- Thorough peer review

- Inclusion in PubMed and all major indexing services

- Maximum visibility for your research

Submit your manuscript at www.biomedcentral.com/submit
C Biomed Central 